Jurnal Onoma: Pendidikan, Bahasa dan Sastra

\title{
Peningkatan Keterampilan Menulis Teks Eksposisi melalui Penerapan Model Pembelajaran Picture And Picture Pada Siswa kelas X TESHA SMK Negeri 3 Makassar
}

\author{
Hasnur Ruslan \\ Pendidikan Bahasa dan Sastra Indonesia \\ Fakultas Keguruan dan Ilmu Pendidikan \\ Universitas Muhammadiyah Makassar \\ hasnurruslan@unismuh.ac.id
}

\begin{abstract}
Abstrak
Peningkatan Keterampilan Menulis Teks Eksposisi Melalui Penerapan Model Pembelajaran picture and picture di kelas X TESHA SMK Negeri 3 Makassar. Penelitian Tindakan Kelas (PTK). Tujuan dari penelitian ini adalah untuk meningkatkan keterampilan menulis teks eksposisi dengan penerapan model pembelajaran picture and picture dalam pelajaran Bahasa Indonesia.Jenis penelitian ini adalah penelitian tindakan kelas yang dilakukan dalam dua siklus yang terdiri dari empat pertemuan. Subyek penelitian ini adalah siswa kelas X TESHA SMK Negeri 3 Makassar yang terdiri dari 25 siswa. Dengan pelaksanaan Model Pembelajaran picture and picture dalam pembelajaran keterampilan menulis bahasa Indonesia, siswa lebih aktif, kooperatif dan melihat kenyataan dalam pembelajaran kemampuan menulis, sehingga pencapaian kemampuan menulis teks eksposisi siswa, meningkat secara signifikan. Dapat dilihat dari hasil tes diagnosis, tes siklus I dan tes siklus II.Nilai rata-rata tes siklus I adalah 52,4. Nilai ini lebih tinggi dari nilai rata-rata tes diagnosis. Tetapi hasil ini belum signifikan dari hasil yang diharapkan sesuai sehingga penelitian dilanjutkan ke siklus II dan pencapaian nilai rata-rata di siklus II adalah 80,4. Nilai ini dikategorikan baik. Hal ini juga mengindikasikan bahwa terdapat nilai yang signifikan dari nilai yang diharapkan yaitu 80,4.

Kata kunci :Keterampilan Menulis, Teks Eksposisi, Picture and Picture.
\end{abstract}

\begin{abstract}
Improving the Skill of Exposing Text Writing Through the Application of Picture and Picture Learning Models in Class X of TESHA SMK Negeri 3 Makassar. Classroom Action Research (CAR). The purpose of this study is to improve the skills of exposition text writing by applying the Picture and Picture learning model in Indonesian language lessons. This type of research is Classroom Action Research conducted in two cycles consisting of four meetings. The subjects of this study were students of class $X$ TESHA Vocational School 3 Makassar consisting of 25 students. With the implementation of the Picture and Picture Learning Model in learning Indonesian writing skills, students are more active, cooperative and see the reality in learning the ability to write, so that the achievement of students' ability to write exposition text increases significantly. Can be seen from the results of the diagnostic test, the first cycle test and the second cycle test.The average value of the first cycle test was 52.4. This value is higher than the average value of the diagnostic test. But these results are not yet significant from the expected results accordingly so the research continues to cycle II and the achievement of the average value in cycle II is 80.4. This value is categorized as good. This also indicates that there is a significant value of the expected value of 80.4 .
\end{abstract}

Keywords: Writing Skills, Exposition Text, Picture and Picture. 
Jurnal Onoma: Pendidikan, Bahasa dan Sastra

ISSN 2443-3667

PBSI FKIP Universitas Cokroaminoto Palopo

ISSN 2715-4564

(Print)

(Online

Volume 7 Nomor 1 Tahun 2021

\section{Pendahuluan}

Menulis adalah menurunkan atau melukiskan lambang-lambang grafik yang menggambarkan suatu bahasa yang dipahami oleh seseorang, sehingga orang lain dapat membaca lambang-lambang grafik tersebut jika mereka memahami bahasa dan gambaran grafik itu (Tarigan, 2008: 22).Keterampilan menulis merupakan salah satu komponen keterampilan berbahasa yang penting dalam kehidupan pendidikan maupun kehidupan bermasyarakat. Kaitannya dengan pembelajaran di sekolah, keterampilan menulis harus dikuasai oleh siswa. Tujuan yang diharapkan dalam pembelajaran menulis di sekolah agar siswa mampu memahami dan dapat mengemukakan ide, gagasan, pendapat, atau perasaan mereka ke dalam bentuk tulisan. Salah satu kompetensi dasar yang harus dicapai oleh siswa kelas XI SMK pada silabus Mata Pelajaran Bahasa Indonesia Kurikulum 2013 adalah kegiatan memproduksi teks eksposisi. Kegiatan memproduksi merupakan bagian dari keterampilan menulis atau menghasilkan tulisan yang menuntut siswa untuk lebih kreatif, inovatif, dan ekspresif dalam mengungkapkan ide atau gagasan. Teks eksposisi merupakan karangan yang menerangkan pokok pikiran yang dapat memperluas wawasan pembaca. Tompkins menjelaskan bahwa tulisan yang bersifat faktual, untuk memberi informasi fakta-fakta penting di dunia (Zainurrahman, 2013: 67).

Teks eksposisi suatu tulisan yang memberikan fakta penting yang terjadi sehingga pengetahuan pembaca bertambah. Dengan teks eksposisi, penulis menjelaskan bagaimana dan mengapa sesuatu itu bisa terjadi. Hal senada juga dijelaskan oleh Zainurrahman (2013: 68), menyatakan bahwa teks eksposisi adalah tulisan yang berisi informasi mengenai mengapa dan bagaimana suatu terjadi, sehingga pembaca memiliki pemahaman mengenai sesuatu. Melalui teks eksposisi penulis berusaha menjelaskan sebuah proses terjadinya sesuatu dan memberikan pemahaman kepada pembaca.Teks eksposisi merupakan sebuah teks yang berisi sebuah informasi yang berupa gagasan pendapat dan fakta yang bertujuan untuk memberikan sebuah informasi dan pengetahuan kepada kita semua mengenai suatu hal (Keraf, G, 1995: 23).

Melalui teks eksposisi penulis berusaha untuk memaparkan suatu ide atau gagasan yang dimilikinya. Paparan yang diberikan biasanya disertai dengan keterangan-keterangan, contoh-contoh, proses, definisi analisis hubungan sebab akibat, fakta, angka, dan grafik. Berdasarkan hasil observasi kegiatan belajar mengajar terdapat beberapa permasalahan yang teridentifikasi, di antaranya siswa sulit untuk mengungkapkan dan mengembangkan ide ke dalam bentuk tulisan teks eksposisi menjadi tulisan yang utuh sesuai dengan struktur dan kebahasaan teks eksposisi, siswa belum meguasai penggunaan ejaan bahasa Indonesia yang tepat, siswa cenderung pasif dalam pembelajaran menulis teks eksposisi serta minat dan motivasi siswa dalam pembelajaran menulis teks eksposisi masih kurang sehingga keterampilan menulis teks eksposisi siswa rendah. Selain itu, guru belum mengoptimalkan model pembelajaran yang bervariasi dalam pembelajaran menulis teks eksposisi sehingga siswa merasa bosan mengikuti pembelajaran.

Menulis adalah menurunkan atau melukiskan lambang-lambang grafik yang menggambarkan suatu bahasa yang dipahami oleh seseorang, sehingga orang lain dapat membaca lambang-lambang grafik tersebut jika mereka memahami bahasa dan gambaran grafik itu (Tarigan, 2008: 22). Jadi, menulis adalah aktivitas mengungkapkan ide, gagasan, dan perasaan dalam bahasa tulis dengan menggunakan lambang-lambang. 


\section{Metode Penelitian}

Pelaksanaan penelitian ini direncanakan dua siklus. Dalam hal ini, siklus I direncanakan dua kali pertemuan. Adapun pelaksanaan tindakan siklus II merupakan kelanjutan dan perbaikan dari pelaksanaan tindakan siklus I. Tidak menutup kemungkinan jika pada siklus II ternyata refleksi menunjukkan bahwa hasil yang diperoleh belum meningkat maka dilanjutkan ke siklus berikutnya

C. Siklus Tindakan

1. Siklus I

Pelaksanaan siklus I dilakukan sebanyak dua kali pertemuan atau empat jam pelajaran dengan alokasi waktu 2 x 45 menit. Siklus pertama ini melalui tiga tahap yaitu: (1) perencanaan tindakan, (2) pelaksanaan tindakan, (3) evaluasi dan refleksi.

a. Rencana Tindakan

1) melakukan diskusi dengan guru mata pelajaran Bahasa Indonesia untuk membahas masalah yang akan dipecahkan melalui model pembeljaran picture and picture.

2) menentukan pokok bahasan yang akan diajarkan yaitu pembelajaran menulis teks eksposisi dengan menggunakan model picture and picture;

3) mempersiapkan perangkat pembelajaran yakni rencana pembelajaran (RPP) yang akan diajarkan;

4) membuat pedoman observasi sebagai pedoman dalam pengamatan;

5) menyusun alat evaluasi;

6) mempersiapkan bahan dan media yang akan digunakan dalam proses pembelajaran.

b. Pelaksanaan Tindakan Melakukan proses pembelajaran sesuai dengan rencana pelaksanaan pembelajaran (RPP) yang telah dibuat.

1) penyampaian kompetensi yang harus dikuasai siswa,

2) penyajian materi dan pemberian motivasi,

3) penyajian gambar untuk diamati oleh siswa,

4) pemasangan/pengurutan gambar oleh siswa secara bergantian menjadi urutan yang logis dan sistematis,

5) penjajakan atas alasan urutan gambar yang disusun oleh siswa,

6) menulis teks eksposisi

7) kesimpulan dengan saling berefleksi mengenai apa yang telah dilakukan.

c. Tahap Observasi dan Evaluasi

Pelaksanaan observasi dilakukan pada saat pembelajaran berlangsung. Observasi dilakukan dengan menggunakan lembar observasi berupa pengamatan. Melakukan evaluasi dengan penugasan unjuk kerja menulis teks ekspalanasi pada siswa dalam kegiatan inti. Tahap ini dilakukan selama pembelajaran menulis teks eksposisi sedang berlangsung. Setelah kinerja siswa diapresiasi berupa skor atau nilai, kemudian skor tersebut dianalisis untuk mengetahui kategori ketercapaian tujuan pembelajaran. Hasilhasil yang diperoleh dan permasalahan yang muncul pada pelaksanaan tindakan dijadikan sebagai dasar untuk melakukan perencanaan ulang pada siklus berikutnya. d. Tahap Refleksi 
Pada tahap ini dilakukan refleksi atau menelaah kembali penelitian ini berdasarkan hasil observasi dan evaluasi selama proses pembelajaran berlangsung. Melibatkan siswa dalam penelitian dengan meminta tanggapan mereka mengenai proses pelaksanaan pembelajaran. Mendiskusikan hasil refleksi yang telah dibuat bersama dengan observer yakni rekan guru mata pelajaran Bahasa dan Sastra Indonesia. Secara terperinci akan dijelaskan berikut ini:

1) hasil yang didapat dari hasil observasi dan analisis akan direfleksikan dengan melihat data observasi dan tes akhir;

2) perlakuan refleksi yang dimaksud adalah pengkajian terhadap keberhasilan atau kegagalan pencapaian sementara;

3) mendiskusikan hasil refleksi yang telah dibuat bersama dengan guru mata pelajaran Bahasa Indonesia;

4) hasil analisis siklus I dijadikan acuan peneliti untuk menentukan tindakan pada siklus berikutnya sesuai dengan yang diharapkan dan hendaknya lebih baik dari siklus sebelumnya dengan kegiatan perencanaan ulang, tindakan ulang, dan pengamatam ulang sehingga permasalahan dapat teratasi, Hopkins (dalam Arikunto dkk., 2010:80).

2. Siklus II

Pada siklus II dilakukan tahapan-tahapan seperti pada siklus I, tetapi didahului dengan perencanaan ulang berdasarkan hasil-hasil yang diperoleh pada siklus I sehingga kendala yang terjadi pada siklus I tidak terjadi pada siklus II.

Pelaksanaan siklus II dilaksanakan selama dua minggu sebanyak empat kali pertemuan. Langkah-langkah yang dilakukan dalam siklus II ini relatif sama dengan yang dilakukan pada siklus I, tetapi pada beberapa langkah dilakukan perbaikan atau penambahan tindakan sesuai dengan kenyataan yang ditemukan di lapangan. Apabila hasil pada siklus II belum maksimal, maka dilanjutkan ke siklus berikutnya sampai tercapai peningkatan hasil belajar.

\section{Pembahasan Hasil Penelitian}

Observasi pembelajaran digunakan untuk mengetahui proses pembelajaran siswa kelas X TESHA SMK Negeri 3 Makassar. Penelitian ini di awali dengan pengamatan penelitian yang berkolaborasi dengan guru kelas X TESHA SMK Negeri 3 Makassar dengan pembelajaran bahasa Indonesia, khususnya pada keterampilan menulis karangan eksposisi. Pengamatan ini dilakukan untuk mengetahui perbandingan hasil kemampuan menulis karangan siswa sebelum dan sesudah menggunakan Model Picture and Picture. Dari hasil pengamatan tersebut diperoleh gambaran tentang proses pembelajaran sebelum tindakan dilaksanakan. Saat pembelajaran berlangsung, sebagian besar siswa asyik dengan permainannya sendiri bahkan ada yang bercanda dengan siswa lain, sehingga mempengaruhi konsentrasi belajar para siswa. Media dan metode pengajaran yang diterapkan guru juga masih monoton membuat siswa merasa bosan dan kurang tertarik mengikuti pelajaran, sehingga hanya sebagian kecil siswa yang memperhatikan saat guru menjelaskan. Konsentrasi dan pemahaman siswa dalam hal menulis karangan pun masih rendah. 
Penelitian ini dilaksanakan di X TESHA SMK Negeri 3 Makassar. Kegiatan proses belajar mengajar (PBM) berlangsung di pagi hari sampai sore hari yaitu pukul $07.15 \mathrm{~s} / \mathrm{d}$ 15.10 .

\section{Deskripsi Pelaksanaan Siklus I a. Perencanaan}

Adapun kegiatan yang dilaksanakan dalam tahap perencanaan adalah:Menelaah materi pelajaran bahasa Indonesia.Membuat pembelajaran dengan menerapkan langkahlangkah model pembelajaran Picture and Picture.Membuat lembar observasi untuk melihat kondisi proses belajar mengajar berlangsung di kelas ketika pendekatan keterampilan proses diaplikasikan. Membuat tes akhir untuk mengetahui hasil belajar bahasa Indonesia.

Pelaksanaan Kegiatan awal Peneliti mengawali pertemuan dengan mengecek kehadiran siswa.Peneliti menyampaikan kompetensi yang ingin dicapai.Peneliti menyiapkan gambar sebagai topik yang akan di buat menjadi sebuah karangan.

Kegiatan intiPeneliti menyiapkan bahan yang dipelajari pada saat itu peserta didik memperhatikan. Setelah selesai menjelaskan guru membagi peserta didik menjadi berkelompok secara heterogenitas.Peneliti menjelaskan dan mencontohkan kepada peserta didik bagaimana maksud dari materi yang akan diajarkan.Peneliti bisa meminta peserta didik untuk memilih apa yang telah mereka inginkan atau yang bisa dilakukan, berkaitan dengan aspek apapun yang berhubungan dengan materi tersebut.Peneliti juga harus bisa meminta peserta didik saling bertukar pikiran sehingga mereka lebih percaya diri. Memberikan kesempatan peserta didik untuk menjelaskan kepada peserta didik lainnya melalui bagan/peta konsep.Peneliti memberikan kesempatan peserta didik untuk menjelaskan kepada peserta didik lainnya misalnya melalui gambar.Peneliti meminta peserta didik untuk menentukan sebuah judul dari tema yang telah peserta didik pilih.Peneliti menjelaskan kepada peserta didik, setelah peserta didik telah memilih tema untuk membuat suatu karangan, guru meminta peserta didik membuat judul yang akan menjadi judul dari karangan yang akan peserta didik buat Peneliti meminta peserta didik mengembangkan tema yang telah peserta didik pilih untuk dijadikan karangan teks eksposisi dan diberikan judul yang tepat.Peneliti meminta peserta didik membacakan atau mempresentasikan hasil karangannya tersebut didepan kelas.

Kegiatan akhirPeneliti bersama siswa menyimpulkan materi pembelajaran.Penilaian Observasi dilakukan terhadap pelaksanaan tindakan dengan menggunakan lembar observasi yang telah disiapkan. RefleksiPada akhir siklus diadakan refleksi terhadap hal-hal yang diperoleh baik dari hasil observasi dan evaluasi kemudian dianalisis. Kekurangan-kekurangan yang terjadi pada siklus 1 diperbaiki pada siklus berikutnya. Pembahasan Analisis Data PenelitianHasil Belajar Siswa Pada Siklus I.Data hasil penelitian pada siswa setelah menerapkan model pembelajaran Picture and Picture dalam pelajaran bahasa Indonesia pada siswa kelas X TESHA SMK Negeri 3 Makassar, selanjutnya dianalisis dengan menggunakan analisis statistik deskriptif yang hasilnya dapat dilihat sebagai berikut: 
Tabel 4.1 Analisis Statistik Deskriptif Pada Siklus I

Nilai (xi) Banyaknya siswa (fi) fi.xi xi2 fi.xi2

45

65

75

40

35

50

55

60

43

80

$\Sigma$

$\begin{array}{llll}3 & 135 & 2025 & 6075 \\ 4 & 260 & 4225 & 16900 \\ 2 & 150 & 5625 & 11250 \\ 3 & 120 & 1600 & 4800 \\ 3 & 105 & 1225 & 3675 \\ 4 & 200 & 2500 & 10000 \\ 1 & 55 & 3025 & 3025 \\ 2 & 120 & 3600 & 7200 \\ 2 & 86 & 1849 & 3698 \\ 1 & 80 & 6400 & 6400 \\ 25 & 1311 & 32074 & 73023\end{array}$

Skor Rata-rata:

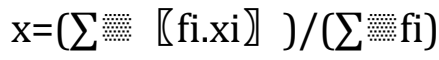

$$
\begin{aligned}
& =1311 / 25 \\
& =52,44 \\
& =80-35 \\
& \text { Rentang Skor }=\text { Skor Maksimum }- \text { Skor Minimum: } \\
& =45 \\
& \text { Standar Deviasi: }
\end{aligned}
$$

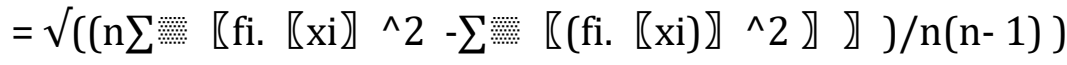

$$
\begin{aligned}
& =\sqrt{ }\left(\left(25(73023)-(1311)^{\wedge} 2\right) / 25(25-1)\right) \\
& =\sqrt{ }((1825575-1718721) /(25 \times 24)) \\
& =\sqrt{ }(106854 / 600) \\
& =\sqrt{178,09}=13,34
\end{aligned}
$$

Tabel 4.2 Statistik Skor Hasil Belajar Teks Eksposisi Pada Siswa Kelas X TESHA SMK Negeri 3 Makassar Pada Siklus I

Statistik

Skor ideal

Skor terendah

Skor tertinggi

Rentang skor

Skor rata-rata

Standar deviasi
Nilai Statistik

100,00

35,00

80,00

45,00

52,44

13,34

Halaman| 149 
Berdasarkan tabel 4.2 di atas dapat digambarkan bahwa hasil siswa kelas X TESHA SMK Negeri 3 Makassar diajar dengan menggunakan model pembelajaran Picture and Picture sebagai berikut:

Gambaran tingkat hasil diajar dengan menggunakan model pembelajaran Picture and Picture adalah skor rata-rata belajar siswa dengan menggunakan model pembelajaran Picture and Picture sebesar 52,44 dari skor ideal 100, menunjukkan bahwa tingkat hasil belajar siswa berada pada kategori " sangat rendah" sesuai dengan standar kategori skor. Apabila nilai hasil belajar siswa kelas X TESHA SMK Negeri 3 Makassar dengan menggunakan model pembelajaran Picture and Picture dikelompokkan dalam lima kategori, maka akan diperoleh distribusi dan persentase seperti pada tabel berikut :

Tabel 4.3 Distribusi Frekuensi dan Persentase Skor Hasil Belajar Teks Eksposisi Pada Siswa Kelas X TESHA SMK Negeri 3 Makassar Pada Siklus I

$\begin{array}{llll}\text { Hasil yang dicapai } & \text { Frekuensi } & \text { Presentase } & \text { Kategori } \\ 0-59 & 16 & 64 \% & \text { Sangat rendah } \\ 60-69 & 6 & 24 \% & \text { Rendah } \\ 70-79 & 2 & 8 \% & \text { Sedang } \\ 80-89 & 1 & 4 \% & \text { Tinggi } \\ 90-100 & 0 & 0 \% & \text { Sangat tinggi } \\ \text { Jumlah } & 25 & 100 & \end{array}$

Berdasarkan Tabel 4.2 dan Tabel 4.3 dapat dinyatakan bahwa skor rata-rata hasil belajar siswa dengan menggunakan model pembelajaran picture and picture sebesar 52,44 dengan standar deviasi 13,34 dari skor ideal 100 berada pada kategori "sangat rendah". Hal ini berarti siswa yang menjadi satuan eksprimen pada umumnya skor bahasa Indonesia menggunakan model pembelajaran picture and picture, termasuk kategori sangat rendah. Selanjutnya data skor hasil belajar siswa dengan pembelajaran bahasa Indonesia dengan menggunakan menggunakan model pembelajaran picture and picture, dianalisis berdasarkan KKM 75,00 pada tabel sebagai berikut:

Tabel 4.4 Deskripsi Ketuntasan Skor Hasil Belajar Teks Eksposisi Pada Siswa Kelas X TESHA SMK Negeri 3 Makassar Pada Siklus I

$\begin{array}{llcl}\text { Interval skor } & \text { Kategori } & \text { Frekuensi } & \text { Persentase } \\ 0 \leq \mathrm{x} \leq 74 & \text { Tidak Tuntas } & 22 & 88 \% \\ 75<\mathrm{x} \leq 100 & \text { Tuntas } & 3 & 12 \%\end{array}$

Dari Tabel 4.4 di atas terlihat bahwa siswa yang tidak tuntas sebanyak 22 orang (88\%) sedangkan siswa yang memenuhi Kriteria Ketuntasan Minimal sebanyak 3 siswa (12\%), dapat disimpulkan bahwa hasil belajar siswa kelas X TESHA SMK Negeri 3 Makassar setelah diterapkan pembelajaran bahasa Indonesia melalui model pembelajaran Picture and Picture tergolong sangat rendah.

\section{Aktivitas Siswa Pada Siklus I}

Instrumen lembar pengamatan aktivitas siswa digunakan untuk mengamati semua aktivitas siswa selama kegiatan pembelajaran berlangsung. Prosedur pengamatan yang 
dilakukan pada saat kegiatan pembelajaran berlangsung, Frekuensi aktivitas siswa terangkum pada Tabel 4.5 sebagai berikut:

Tabel 4.5 Analisis Aktivitas Siswa Kelas X TESHA SMK Negeri 3 Makassar Pada Siklus I

Komponen

pertemuan ke

Rata-rata

Presentase

1. Siswa yang hadir.

$19 \quad 22$

2. Siswa yang memperhatikan materi. $10 \quad 12$

20,5

$82 \%$

3. Siswa yang mengajukan pertanyaan

tentang materi pelajaran yang belum dipa

hami pada saat proses belajar mengajar

berlangsung.

22

11

$44 \%$

$4 \quad$ Siswa yang aktif mengerjakan

soal-soal latihan yang di berikan.

5. Siswa yang masih membutuhkan

bimbingan dalam mengerjakan

tugas-tugas yang diberikan.

6. Siswa yang aktif mempresentasikan

hasil kerjanya di depan kelas. 2

23

$3 \quad 2,5$

$20 \%$

7. Siswa yang mengerjakan aktivitas lain di kelas, selama proses belajar mengajar berlangsung. $\quad 2 \quad 3$

8. Siswa yang keluar masuk kelas. $\quad 2 \quad 3$ Jumlah

Tabel di atas menunjukan bahwa siswa yang hadir pada pertemuan pertama sampai kedua pada siklus I sebanyak 82\%, dan siswa yang memperhatikan materi sebanyak 44\%. Siswa yang mengajukan pertanyaan tentang materi pelajaran yang belum dipahami pada saat proses belajar mengajar berlangsung, pada pertemuan pertama sampai pertemuan kedua pada siklus I dengan rata-rata 2 dengan persentase $16 \%$. Siswa yang aktif mengerjakan soal-soal latihan yang di berikan dengan rata-rata 10 dengan persentase $40 \%$, sedangkan siswa yang masih membutuhkan bimbingan dalam mengerjakan tugas-tugas yang diberikan pada pertemuan pertama dan kedua pada seklus I dengan rata-rata 6,5 dengan persentase $26 \%$. Siswa yang mengerjakan aktivitas lain di kelas selama proses belajar mengajar berlangsung dan siswa yang keluar masuk kelas pada pertemuan pertama dan kedua pada siklus I dengan rata-rata 2,5 dengan persenan $20 \%$, dengan jumlah akhir 258\%

\section{Hasil belajar Siswa Pada Siklus II}

Data hasil penelitian pada siswa setelah menerapkan model pembelajaran Picture and Picture dalam pelajaran bahasa Indonesia pada siswa kelas X TESHA SMK Negeri 3 Makassar, selanjutnya dianalisis dengan menggunakan analisis statistik deskriptif yang hasilnya dapat dilihat sebagai berikut: 
Tabel 4.6 Analisis Statistik Deskriptif Pada Siklus II

$\begin{array}{lllll}\text { Nilai (xi) } & \text { Banyaknya siswa (fi) fi.xi } & \text { xi2 } & \text { fi.xi2 } \\ 70 & 4 & 280 & 4900 & 19600 \\ 75 & 5 & 375 & 5625 & 28125 \\ 77 & 2 & 154 & 5929 & 11858 \\ 83 & 5 & 415 & 6889 & 34445 \\ 80 & 2 & 160 & 6400 & 15450 \\ 85 & 3 & 255 & 7225 & 21765 \\ 90 & 2 & 180 & 8100 & 16200 \\ 95 & 1 & 95 & 9025 & 9025 \\ 97 & 1 & 97 & 9409 & 9409 \\ \sum & 25 & 2011 & 63502 & 165877\end{array}$

Skor Rata-rata:

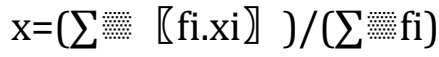

$=22011 / 25$

$=80,44$

Rentang Skor $=$ Skor Maksimum-Skor Minimum:

$=97-70$

$=27$

Standar Deviasi:

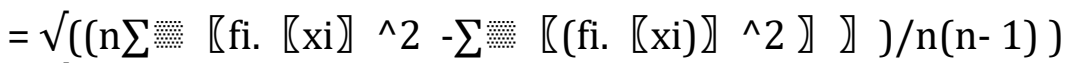

$=\sqrt{\left(\left(25(165877)-(2011)^{\wedge} 2\right) / 25(25-1)\right)}$

$=\sqrt{ }((4146925-4044121) /(25 \times 24))$

$=\sqrt{ }(102804 / 600)$

$=\sqrt{171,44}$

$=13,09$

Tabel 4.7 Statistik Skor Hasil Belajar Teks Eksposisi Pada Siswa Kelas X TESHA SMK Negeri 3 Makassar Pada Siklus II

Statistik Nilai Statistik

Skor ideal $\quad 100$

Skor terendah $\quad 70,00$

Skor tertinggi $\quad 97,00$

Rentang skor $\quad 27,00$

Skor rata-rata $\quad 80,44$

Standar deviasi $\quad 13,09$

Berdasarkan tabel 4.7 di atas dapat digambarkan bahwa hasil belajar siswa kelas X TESHA SMK Negeri 3 Makassar menerapkan model pembelajaran Picture and Picture sebagai berikut:

Gambaran tingkat hasil belajar siswa setelah diajar dengan menggunakan menerapkan model pembelajaran Picture and Picture sebagai berikut:

Skor rata-rata hasil belajar siswa setelah diajar dengan menggunakan model pembelajaran Picture and Picture sebesar 80,44 dari skor ideal 100, menunjukkan bahwa 
tingkat hasil belajar siswa setelah diberi perlakuan berada pada kategori " tinggi" sesuai dengan standar kategori skor.

Standar deviasi sebesar 13,09 dan rentang skor yang merupakan jarak antara skor terendah dan skor tertinggi sebesar 27,00. Apabila nilai hasil belajar siswa kelas X TESHA SMK Negeri 3 Makassar setelah menerapkan model pembelajaran Picture and Picture dikelompokkan dalam lima kategori, maka akan diperoleh distribusi dan persentase.

Tabel 4.8 Distribusi Frekuensi dan Persentase Skor Hasil Belajar Teks Eksposisi Pada Siswa Kelas X TESHA SMK Negeri 3 Makassar Pada Siklus II

$\begin{array}{lcll}\text { Hasil yang dicapai } & \text { Frekuensi } & \text { Presentase } & \text { Kategori } \\ 0-59 & 0 & 0 \% & \text { Sangat rendah } \\ 60-69 & 0 & 0 \% & \text { Rendah } \\ 70-79 & 11 & 44 \% & \text { Sedang } \\ 80-89 & 12 & 48 \% & \text { Tinggi } \\ 90-100 & 3 & 12 \% & \text { Sangat tinggi } \\ \text { Jumlah } & 25 & 100 & \end{array}$

Selanjutnya data skor hasil belajar siswa setelah pembelajaran bahasa Indonesia dengan model pembelajaran Picture and Picture berdasarkan KKM 75,00 pada tabel sebagai berikut:

Tabel 4.9 Deskripsi Ketuntasan Skor Hasil Belajar Teks Eksposisi Pada Siswa Kelas X TESHA SMK Negeri 3 Makassar Pada Siklus II

$\begin{array}{llll}\text { Interval skor } & \text { Kategori } & \text { Frekuensi } & \text { Persentase } \\ 0 \leq \mathrm{x} \leq 74 & \text { Tidak Tuntas } & 4 & 16 \% \\ 75<\mathrm{x} \leq 100 & \text { Tuntas } & 21 & 84 \%\end{array}$

Dari Tabel 4.9 di atas terlihat bahwa siswa yang tidak tuntas sebanyak 4 orang (16\%), sedangkan siswa yang memenuhi Kriteria Ketuntasan Minimal sebanyak 21 siswa (84\%), dapat disimpulkan bahwa hasil belajar siswa kelas X TESHA SMK Negeri 3 Makassar setelah diterapkan pembelajaran bahasa Indonesia melalui model pembelajaran Picture and Picture tergolong tinggi.

\section{d. Aktivitas Siswa Pada Siklus II}

Instrumen lembar pengamatan aktivitas siswa digunakan untuk mengamati semua aktivitas siswa selama kegiatan pembelajaran berlangsung. Prosedur pengamatan yang dilakukan pada saat kegiatan pembelajaran berlangsung, Frekuensi aktivitas siswa terangkum pada Tabel 4.5 sebagai berikut:

Tabel 4.10 Analisis Aktivitas Siswa Kelas X TESHA SMK Negeri 3 Makassar Pada Siklus II

No Komponen Pertemuan ke-1 rata-rata presentase

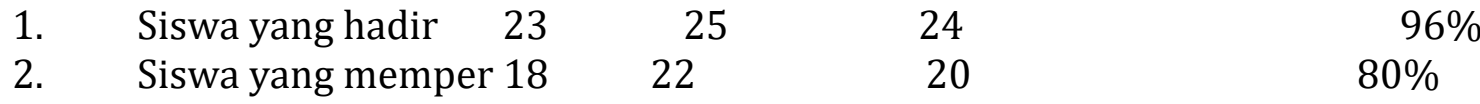
hatikan materi.

3. Siswa yang mengajukan $4 \quad 5 \quad 4.5 \quad 18 \%$ pertanyaan tentang 
materi pelajaran

yang belum dipa

hami pada saat proses

belajar mengajar berlangsung.

18

22

20

$80 \%$

$4 \quad$ Siswa yang aktif mengerjakan

soal-soal latihan yang di berikan.

5. Siswa yang masih membutuhkan

bimbingan dalam mengerjakan

tugas-tugas yang diberikan.

6. Siswa yang aktif mempresentasikan 43

hasil kerjanya di depan kelas.

\section{Siswa yang mengerjakan aktivitas}

lain di kelas, selama proses belajar

mengajar berlangsung.

8. Siswa yang keluar masuk kelas. $\quad 0 \quad 1$

Jumlah

22

3.5

$14 \%$

3

$12 \%$

Tabel di atas menunjukan bahwa siswa yang hadir pada pertemuan pertama sampai kedua pada siklus II sebanyak 96\%, dan siswa yang memperhatikan materi sebanyak $80 \%$. Siswa yang mengajukan pertanyaan tentang materi pelajaran yang belum dipahami pada saat proses belajar mengajar berlangsung, pada pertemuan pertama sampai pertemuan kedua pada siklus II dengan rata-rata 4,5 dengan persentase $18 \%$. Siswa yang aktif mengerjakan soal-soal latihan yang di berikan dengan rata-rata 20 dengan persentase $80 \%$, sedangkan siswa yang masih membutuhkan bimbingan dalam mengerjakan tugas-tugas yang diberikan pada pertemuan pertama dan kedua pada seklus II dengan rata-rata 3 dengan persentase $12 \%$. Siswa yang mengerjakan aktivitas lain di kelas selama proses belajar mengajar berlangsung sebanyak 8\% dan siswa yang keluar masuk kelas pada pertemuan pertama dan kedua pada siklus II dengan rata-rata 0,5 dengan persenan $4 \%$, dengan jumlah akhir $312 \%$

\section{Pembahasan}

Berdasarkan hasil penelitian yang telah diuraikan pembahasan hasil penelitian yang meliputi pembahasan hasil analisis. Pembahasan hasil analisis tentang skor hasil belajar siswa pada siklus I dan siklus II, serta aktivitas siswa dalam pembelajaran bahasa Indonesia melalui model pembelajaran Picture and Picture, Kedua aspek tersebut akan diuraikan sebagai berikut:

\section{Skor Hasil Belajar Siswa pada Siklus I Melalui Model Pembelajaran Picture and Picture}

Hasil analisis data skor hasil belajar siswa dalam pembelajaran teks eksposisi pada siklus I dengan menggunakan model pembelajaran Picture and Picture menunjukkan bahwa 25 siswa (64\%), dengan skor rata-rata 52,44 tidak mencapai KKM dan standar deviasi 13,34 dengan skor maksimum 100, berada dalam kategori sangat rendah sehingga interval skor pada siswa di siklus I, $0 \leq \mathrm{x} \leq 74$ dengan persentase $88 \%$ dengan jumlah siswa tidak tuntas sebanyak 22 dan tuntas sebanyak 3 orang, sehingga dapat disimpulkan bahwa penelitian pada siklus pertama tidak tuntas, dilihat dari pencapaian siswa pada 
aspek menulis teks eksposisi yang menunjukkan rata-rata kelemahan siswa terletak pada isi dan kosakata, yang merupakan aspek terpenting dalam teks ekposisi sehingga disimpulkan tidak adanya peningkatan pada skor hasil belajar siswa dengan menggunakan Picture and Picture.

\section{Skor Hasil Belajar Siswa pada Siklus II Melalui Model Pembelajaran Picture and Picture}

Hasil analisis data skor hasil siswa yang tidak tuntas sebanyak 4 orang (16\%) sedangkan siswa yang memenuhi kriteria ketuntasan minimal sebanyak 21 murid (84\%), dapat disimpulkan bahwa hasil belajar murid kelas X TESHA SMK Negeri 3 Makassar setelah diterapkan pembelajaran Teks Eksposisi melalui model pembelajaran Picture and Picture tergolong tinggi. Hasil analisis skor rata-rata hasil belajar siswa setelah diajar dengan menggunakan model pembelajaran picture and picture sebesar 80,44 dari skor ideal 100.

Melihat indikator keberhasilan maka dapat dikatakan penelitian ini berhasil, terbukti dari jumlah keseluruhan siswa kelas X TESHA SMK Negeri 3 Makassar yang berjumlah 25 siswa meningkat. Ternyata model Picture and Picture bagus digunakan karena mampu meningkatkan hasil belajar siswa. Dilihat dari keunggulan model Picture and Picture yaitu materi yang diajarkan lebih terarah karena pada awa lpembelajaran guru menjelaskan kompetensi yang harus dicapai dan materi secara singkat terlebih dahulu; (b) Siswa lebih cepat menangkap materi ajar karena guru menunjukkan gambar -gambar mengenai materi yang dipelajari; (c) Dapat meningkatkan daya nalar atau daya pikir siswa karena siswa ditugaskan guru untuk menganalisa gambar yang ada; (d) Dapat meningkatkan rasa tanggung jawab siswa, sebab guru menanyakan alasan siswa ketika mengurutkan gambar yang ditugaskan; dan (e) Pembelajaran lebih berkesan, sebab siswa dapat mengamati langsung gambar yang telah dipersiapkan oleh guru.

Berdasarkan data-data di atas, melihat perbandingan antara analisis akitivitas dan hasil tes belajar siswa yang dilakukan pada siklus I dan siklus II pada akhinya disimpulkan bahwa penerapan Model pembelajran picture and picture dapat meningkatkan keterampilan menulis teks laporan eksposisi siswa Kelas X THESA SMK Negeri 3 Makassar.

\section{Simpulan}

Berdasarkan hasil penelitian di SMK Negeri 3 Makassar tahun ajaran 2019/2020 dan analisis penulis, dapat disimpulkan bahwa model pembelajaran picture and picture dapat meningkatkan keterampilan menulis teks eksposisi siswa dari rata-rata skor nilai ketuntasan siswa sebesar $12 \%$ pada siklus I menjadi $84 \%$ pada siklus II, artinya terjadi peningkatan sebesar pada siswa kelas X TESHA SMK Negeri 3 Makassar, model pembelajaran Picture and Picture dapat meningkatkan keterampilan menulis teks eksposisi siswa kelas X TESHA SMK Negeri 3 Makassar. Aktivitas belajar meningkat terlihat jelas pada distribusi observasi keterampilan menulis teks eksposisi dengan menggunakan model Picture and Picture. 


\section{Daftar Pustaka}

Arikunto, Suharsimi. 2010. Penelitian Tindakan Kelas. Jakarta: PT. Bumi Aksara.

Kemendikbud. 2013. Buku Guru Bahasa Indonesia Wahana Pengetahuan SMP/ MT.s Kelas VII. Jakarta Kemendikbud.

Keraf, G. 1995. Eksposisi Lanjutan II Jakarta: Gramedia Widiasarana Indonesia

Munirah dan Hardian. 2016. "Pengaruh Kemampuan Kosakata Dan Struktur Kalimat Terhadap Kemampuan Menulis Paragraf Deskripsi Siswa SMA." Jurnal Bahasa dan $\begin{array}{llllll}\text { Sastra Vol } & 16 & \text { No. } & 1 . & \text { http:// } & \text { http://ejournal.upi.edu }\end{array}$ /index.php/BS_JPBSP/article/view/3064

Riska. 2016. "Peningkatan Keterampilan Menulis Teks Eksposisi Kompleks Melalui Model Kooperatif tipe Think Pair Share (TPS) Berbasis Media Audio Visual Pada Siswa Kelas XI SMA Negeri 1 Petanahan Tahun Ajaran 2015/2016". Skripsi. Universitas Negeri Semarang.

Selia. 2014. "Peningkatan Keterampilan Menulis Teks Eksposisi dengan Pendekatan Ilmiah Model Pembelajaran Berbasis Proyek pada Siswa Kelas VII G SMP N 1 Kunduran Kabupaten Blora Tahun Pelajaran 2013/2014". Skripsi. Universitas Negeri Semarang.

Sobandi. 2014. Mandiri Bahasa Indonesia untuk SMA Kelas XI Kurikulum 2013. Jakarta: Erlangga.

Sukirno. 2013. Belajar Cepat Menulis Kreatif Berbasis Kuantum. Yogyakarta: Pustaka Pelajar.

Sunarsih. 2016. "Peningkatan Keterampilan Menulis Teks Eksposisi Kompleks Melalui Media Audio Visual dengan Model Concept Sentence Pada Siswa Kelas XI SMA N 1 Pejagoan Tahun Pelajaran 2015/2016." Skripsi Universitas Negeri Semarang.

Tarigan, Henry Guntur. 2008. Menulis Sebagai suatu Keterampilan .Berbahasa. Bandung: Angkasa

Zainurrahman. (2013). Menulis : Dari Teori Hingga Praktik (penawar Racun Plagiarisme). Bandung : Alfabeta 